\title{
Characteristics of Soil under Greengram-Plum based Agroforestry System in Kashmir Valley, India
}

\author{
Murtaza Hussain Shah ${ }^{1}$, Vaishnu Dutt ${ }^{1}$, S.J.A. Bhat ${ }^{1}$, \\ Zubair A. Dar ${ }^{2}$ and Mehraj ud din Khanday ${ }^{3}$ \\ ${ }^{1}$ Faculty of Forestry, Sher-e-Kashmir University of Agricultural Sciences and \\ Technology of Kashmir, Benihama, Ganderbal-191 201, India \\ ${ }^{2}$ Division of Environmental Sciences, ${ }^{3}$ Division of Soil Science Skuast-Kashmir-190025, India \\ *Corresponding author
}

\section{A B S T R A C T}

\begin{tabular}{l} 
K e y w o r d s \\
Characteristics, \\
Agroforestry, \\
Greengram, \\
Plum, Fertilizers, \\
Organic manure. \\
Article Info \\
\hline $\begin{array}{l}\text { Accepted: } \\
17 \text { April } 2017 \\
\text { Available Online: } \\
10 \text { May } 2017\end{array}$ \\
\hline
\end{tabular}

Keywords

Characteristics, Agroforestry,

Greengram,

Plum, Fertilizers,

Article Info

Accepted:

17 April 2017

10 May 2017

\begin{abstract}
The present investigation was carried out at experimental Farm of the Division of Fruit Science, Sher-e-Kashmir University of Agricultural Sciences and Technology of Kashmir, Shalimar, Srinagar during the year 2011 and 2012 to study the physical and chemical properties of soil. The experiment was laid out in a randomized block design with three replications comprising seven treatments and sole cropping of green gram and plum as controls. The tree spacing was $4 \times 4 \mathrm{~m}$ and spacing of $40 \times 10 \mathrm{~cm}$ for green gram intercrop was maintained. Seeds were sown in the month of July, 2011. The different doses of organic manures and fertilizers and green gram intercrop had a positive role in making the nutrients more available. Among the different doses of organic manures and fertilizers, 80 per cent of recommended doses of NPK + FYM + Dal weed + Biofertilizer (rhizobium) were found to be most efficient. The use of organic manures and fertilizers in combination has been found to be more efficient than organic manures alone. Different doses of organic manures and fertilizers are found to be having influence on available nitrogen, available potassium and available phosphorus.
\end{abstract}

\section{Introduction}

Agroforestry, the relatively new name for the old practice of growing trees and crops in interacting combination, is now recognized as an approach to increasing farm productivity in low - external - input, resource - limited situations. Many, if not most, agroforestry systems have developed over long periods of time in response to interactions between agroecological conditions, plant diversity, and farmer resources and needs. This new concept which came to be known as agroforestry today is even more relevant in the context of growing human and livestock population especially in developing countries like India. According to Asian survey of Agrarian reforms and rural development sponsored by FAO, 1970 per cent of Indian farmers have marginal land holdings which are living much below the poverty line and the ultimate solution of their economic upliftment lies in the establishment of agro/wood, agro/fruit tree based industry at village level. Though, agroforestry appears to be the lone logical solution for sustainable livelihood. It is an integrated land use approach, including cultivation of woody perennials, fruit trees in 
association with annual crops and holds immense potential to ensure stability and sustainability in production and to provide ecological and economic security as compared to conventional system of monocropping. However, to prove its credibility this farming system requires appropriate selection of tree crop-combinations so as to use available resource most efficiently (Huxley, 1996). In an agroforestry system competitive interaction develops between trees and crops for the limiting resources, aboveground for light and below ground for soil, water and nutrients. Asymmetry in resource utilization in agroforestry is due to difference in establishment timing of trees and crops (Bhatt et al., 2003).

Fruit producing species like apple, plum, etc. are the best studied example of intensive fruit tree based agroforestry (Fernandes and Nair, 1986). Plum, an important temperate stone fruit belongs to family Rosaceae and subfamily Prunoideae. It ranks next to peaches in economic importance. Being a delicious juicy fruit, it is used both as fresh and in preserved form. Besides having medicinal properties, it is a fairly good source of citric acid, sugars and vitamin A (Westwood, 1993). In Jammu and Kashmir, the area under plum is 4397 hectares with an annual production of 8603 metric tonnes (Anonymous, 2011). Pulses occupy an indispensable position in the dietary habit of vast majority in the Indian subcontinent. Besides, being nutritionally fulfilling, these contribute to the restoration of the soil fertility. Pulses are mostly of short duration, fit better in rotation and can be grown as main, inter, catch, green manure or cover crop that keeps the soil medium productive and sustainable. In India, pulses are grown on an area of 4.02 million hectares, with production and productivity at 6.43 million tones and $593 \mathrm{~kg} \mathrm{ha}^{-1}$, respectively (Anonymous, 2012). In Jammu and Kashmir state, pulses cover an area of 29.99 thousand hectares, with production and productivity at
138.89 thousand quintals and 4.63 quintals per hectare, respectively (Anonymous, 2010). The experiment was planned to find out the effect of different doses of organic manures and fertilizers on physico-chemical properties of greengram and plum under plum-based agroforestry system and to compare the properties before and after the experiment.

\section{Materials and Methods}

The experimental orchard, the study area, is situated at a latitude of $32^{\circ} \mathrm{N}$ and an altitude of 1650 meters above sea level. The study area lies in temperate zone of Jammu and Kashmir State, which received an annual rainfall of $23.7 \mathrm{~mm}$. The average maximum monthly temperature ranged from 18 to $35{ }^{\circ} \mathrm{C}$ and average minimum monthly temperature varied from 7.4 to $21.5^{\circ} \mathrm{C}$.

\section{Soil characteristics}

Before laying out the experiment, random soil samples were collected from the depth of 0-20 $\mathrm{cm}$ from different spots and the composite sample was prepared which was analysed for various soil characteristics in order to get beforehand information about the physicochemical properties of the soil. The methods employed and results obtained for important physico-chemical characteristics (initial) of the soil of experimental area have been summarized in table 1 .

At the completion of the experiment, the samples from each plot were again drawn and analyzed for various characteristics by the standard methods.

\section{Soil moisture (\%)}

The soil moisture content was determined gravimetrically. Before laying out the experiment, random soil samples were collected up to the depth of $20 \mathrm{~cm}$, by using auger and the composite sample was 
prepared. The composite sample was dried at $105^{\circ} \mathrm{C}$ till constant weight and the soil moisture content was calculated as under:

$$
\begin{array}{lll}
\text { Soil moisture (\%) } & \begin{array}{l}
\text { Fresh weight }- \text { Dry } \\
\text { weight }
\end{array} & \\
\cline { 2 - 3 } & \text { Fresh weight } &
\end{array}
$$

At the completion of the experiment, the samples from each plot were again drawn and soil moisture (\%) content was determined.

\section{Methodology}

The green-gram crop was studied with respect to the soil physico-chemical properties of soil in response to organic manures and fertilizers in an agri-horticulture system. The experimental details followed and methods adopted are given below:

$\begin{array}{lll}\text { Agroforestry system } & : & \text { Agri-horticulture } \\ \text { Structural components } & : & \text { The system was based on the following components } \\ \text { Agricultural crop } & : & \text { Greengram or Mung bean (Vigna radiata) (SM-1) } \\ \text { Tree component } & : & \text { Plum (Prunus salicina) cv. Santa Rosa } \\ \text { Tree spacing } & : & 4 \times 4 \mathrm{~m} \\ \text { Age of the tree component } & : & 6 \text { years } \\ \text { Spacing for greengram } & : & 40 \times 10 \mathrm{~cm} \\ \text { intercrop } & : & 9 \\ \text { Number of treatments } & : & 03 \\ \text { Replications } & : & 27 \\ \text { Total Number of plots } & : & \text { RBD (Randomized Block Design) } \\ \text { Design } & \end{array}$

\section{Treatments}

\begin{tabular}{llll}
\hline Symbol & Treatment & \\
\hline $\mathrm{T}_{1}$ & Control (only Plum) & $:$ No Manure and Fertilizer applied \\
$\mathrm{T}_{2}$ & Control (only Greengram) & $:$ No Manure and Fertilizer applied \\
$\mathrm{T}_{3}$ & $\mathrm{FYM}$ & $: 2 \mathrm{t} / \mathrm{ha}$ \\
$\mathrm{T}_{4}$ & Dalweed Manure & $: 2 \mathrm{t} / \mathrm{ha}$ \\
$\mathrm{T}_{5}$ & Biofertiliser (Rhizobium) & $: 5 \mathrm{~g} / \mathrm{kg} \mathrm{seed}$ \\
$\mathrm{T}_{6}$ & Vermicompost & $: 1 \mathrm{t} / \mathrm{ha}$ \\
$\mathrm{T}_{7}$ & Biofertiliser + Vermicompost & $: 5 \mathrm{~g} / \mathrm{kg} \mathrm{seed}+500 \mathrm{~kg} / \mathrm{ha}$ \\
& $(50 \%)$ & \\
\hline
\end{tabular}

\section{Statistical analysis}

All the data obtained were subjected to the statistical analysis as per procedure given by Gomez and Gomez (1984) using R-Software.

\section{Results and Discussion}

The present investigation entitled "Physicochemical properties of soil under GreengramPlum based Agroforestry System in Kashmir valley" was carried out at the experimental farm of the Division of Fruit Science, Sher-e-
Kashmir University of Agricultural Sciences and Technology of Kashmir, Shalimar, Srinagar during the year 2011 and 2012. The data recorded on different soil characters were statistically analyzed and significance of results was verified.

\section{Soil pH}

The data pertaining to the effect of different levels of organic manures and fertilizers on soil $\mathrm{pH}$ are given in table 2 . It indicates that the treatments significantly influenced $\mathrm{pH}$. 
The highest value (6.89) of $\mathrm{pH}$ was observed under treatment $\mathrm{T}_{8}$ supplied with 80 per cent of recommended doses of NPK + FYM + dalweed + biofertilizer (Rhizobium), followed by $\mathrm{T}_{9}(6.85)$ in which plants were supplied with 60 per cent of recommended doses of $\mathrm{NPK}+\mathrm{FYM}+$ dalweed + biofertilizer (Rhizobium) and the least value (6.41) was found in $\mathrm{T}_{1}$ i.e. control (only plum without organic manure and fertilizer application).

\section{Electrical conductivity}

A perusal of data enumerated in table 2 reveals that all the treatments had a significant influence on electric conductivity (EC). In the depth $0-20 \mathrm{~cm}, 0.33 \mathrm{dSm}^{-1}$ was the highest value of $\mathrm{EC}$ under treatment $\mathrm{T}_{8}$ i.e., plots supplied with 80 per cent of recommended doses of NPK + FYM + dalweed + biofertilizer (Rhizobium), followed by $\mathrm{T}_{9}$ $\left(0.32 \mathrm{dSm}^{-1}\right)$ in which plots were supplied with 60 per cent of recommended doses of $\mathrm{NPK}+\mathrm{FYM}+$ dalweed + biofertilizer (Rhizobium) and the least value $\left(0.26 \mathrm{dSm}^{-1}\right)$ was found in $\mathrm{T}_{1}$ i.e., control (only plum without organic manure and fertilizer application).

\section{Soil moisture}

A perusal of data enumerated in table 2 reveals that all the treatments had a significant influence on soil moisture. The highest value $(6.40 \%)$ of soil moisture was observed under $\mathrm{T}_{8}$ supplied with 80 per cent of recommended doses of NPK + FYM + dalweed + biofertilizer (Rhizobium) followed by $\mathrm{T}_{6}$ $(6.20 \%)$ in which plants were supplied with vermicompost and the least $(5.60 \%)$ was found in $\mathrm{T}_{2}$ i.e., control (sole cropping of greengram without organic manure and fertilizer application).

\section{Available nitrogen}

Application of different doses of organic manures and fertilizers significantly influenced the available $\mathrm{N}$ content of soil (Table 2). In the surface soil $(0-20 \mathrm{~cm})$, the maximum available $\mathrm{N}$ (346.82 $\mathrm{kg} \mathrm{ha}^{-1}$ ) was recorded for the treatment $\mathrm{T}_{8}$ where plants were supplied with 80 per cent of recommended doses of NPK + FYM + dalweed + biofertilizer (Rhizobium) followed by treatment $\mathrm{T}_{9}\left(343.13 \mathrm{~kg} \mathrm{ha}^{-1}\right)$ where plants were supplied with 60 per cent of recommended doses of NPK + FYM + dalweed + biofertilizer (Rhizobium). In the same depth the least value (332.00) of available $\mathrm{N}$, was observed in $\mathrm{T}_{1}$ i.e. control (only plum without organic manure and fertilizer application).

\section{Available phosphorus}

It is evident from the data in table 2 that different doses of organic manures and fertilizers significantly influenced the available $P$ content of soil. In the surface soil $(0-20 \mathrm{~cm})$, the maximum available $\mathrm{P}(23.15$ $\mathrm{kg} \mathrm{ha}^{-1}$ ) was recorded for the treatment $\mathrm{T}_{8}$, where plants were supplied with 80 per cent of recommended doses of NPK + FYM + dalweed + biofertilizer (Rhizobium), followed by $\mathrm{T}_{9}\left(21.00 \mathrm{~kg} \mathrm{ha}^{-1}\right)$. In the same depth the least value for available $\mathrm{P}\left(17.11 \mathrm{~kg} \mathrm{ha}^{-1}\right)$ was observed in treatment $\mathrm{T}_{2}$ i.e., control (only greengram without organic manure and fertilizer application.

\section{Available potassium}

A perusal of data enumerated in table 2 reveal that there was significant effect of different treatments on available $\mathrm{K}$ content of soil. In the surface soil $(0-20 \mathrm{~cm})$, the maximum available $\mathrm{K}$ (150.82 $\mathrm{kg} \mathrm{ha}^{-1}$ ) was recorded for the treatment $\mathrm{T}_{8}$ where plants were supplied with 80 per cent of recommended doses of $\mathrm{NPK}+\mathrm{FYM}+$ dalweed + biofertilizer (Rhizobium), followed by $\mathrm{T}_{9}\left(147.32 \mathrm{~kg} \mathrm{ha}^{-1}\right)$ $\left(136.40 \mathrm{~kg} \mathrm{ha}^{-1}\right)$ was observed in $\mathrm{T}_{1}$ i.e. control (only plum without organic manure and fertilizer application). 
The present study was undertaken to investigate the effect of different doses of organic manures and fertilizers on phsicochemical properties of soil under greengram plum-based agroforestry system. The findings of the study are discussed in light of the available literature.

The application of different doses of organic manures and fertilizers found to have influence on EC $\left(\mathrm{dSm}^{-1}\right)$, soil moisture, available nitrogen, available phosphorus, available potassium and soil $\mathrm{pH}$ (Table 2).

The present study revealed that as the amount of organic manure is increased, there was a decline in the values of $\mathrm{pH}$. The slight decline in the soil $\mathrm{pH}$ under organic manure treatment could be attributed to the production of organic acids formed during decomposition of organic matter. The results are in accordance with the findings of Srikanth et al., (2000) and Jayabhaskaran et al., (2001), who also reported a decline in the soil $\mathrm{pH}$ with application of poultry manure and vermicompost.

The data pertaining to electrical conductivity revealed that application of organic manures and fertilizers significantly influenced electrical conductivity during the study. Soils which had received organic manures and fertilizers recorded more increase in EC over initial value which is obviously due to addition of salts in the soil. These results are in line with the findings of Vijay et al., (2007).

The data pertaining to soil moisture reveal that application of organic manures and fertilizers significantly influenced soil moisture during the study. The increase in soil moisture (\%) can be attributed to the improvement in soil structure and water holding capacity of the soil due to addition of organic manures. These results are in line with the findings of Gupta et al., (1977), Khaleel et al., (1981), Metzger and Yaron (1987). Bijalwan (2010) reported that soil moisture was higher in agri-horticulture compared to sole agriculture (tree less or control). The highest moisture status of soil can also be attributed to reduction in water evaporation, therefore, conserving the available water in soil (Agele, 2000).

Table.1 Physico-chemical properties of soil before planting $(0-20 \mathrm{~cm})$

\begin{tabular}{|c|c|c|c|}
\hline $\begin{array}{l}\text { S. } \\
\text { No. }\end{array}$ & Parameters & $\begin{array}{c}\text { Test } \\
\text { value }\end{array}$ & Method employed \\
\hline 1. & Soil pH & 6.90 & $\begin{array}{l}\text { Glass electrode method } \\
\text { (Jackson, 1973) }\end{array}$ \\
\hline 2. & $\begin{array}{l}\text { Electric conductivity }\left(\mathrm{dSm}^{-1}\right) \text { at } \\
25^{\circ} \mathrm{C}(1: 2 \text { soil-water suspension })\end{array}$ & 0.28 & $\begin{array}{l}\text { Solu bridge conductivity } \\
\text { meter (Piper, 1966) }\end{array}$ \\
\hline 3. & Soil moisture (\%) & 5.31 & Gravimetric method \\
\hline 4. & Available nitrogen $\left(\mathrm{kg} \mathrm{ha}^{-1}\right)$ & 328.6 & $\begin{array}{l}\text { Alkaline permagnate method } \\
\text { (Subbiah and Asija, 1956) }\end{array}$ \\
\hline 5. & Available phosphorus $\left(\mathrm{kg} \mathrm{ha}^{-1}\right)$ & 16.8 & $\begin{array}{l}\text { Olsen method (Olsen et al., } \\
\text { 1954) }\end{array}$ \\
\hline 6. & Available potassium $\left(\mathrm{kg} \mathrm{ha}^{-1}\right)$ & 130.8 & $\begin{array}{l}\text { Flame Photometer method } \\
\text { (Jackson, 1973) }\end{array}$ \\
\hline
\end{tabular}


Table.2 Effect of organic manure and fertilizers on available nutrients and physical properties at the time harvesting of greengram

\begin{tabular}{|c|c|c|c|c|c|c|c|}
\hline & \multirow[b]{2}{*}{ Treatment } & \multicolumn{3}{|c|}{ Available nutrient content $\left(\mathrm{kg} \mathrm{ha}^{-1}\right)$} & \multirow[b]{2}{*}{ Soil pH } & \multirow{2}{*}{$\begin{array}{c}\mathrm{EC} \\
\left(\mathrm{dSm}^{-1}\right)\end{array}$} & \multirow{2}{*}{$\begin{array}{c}\text { Soil } \\
\text { moisture } \\
(\%)\end{array}$} \\
\hline & & Nitrogen & Phosphorus & Potassium & & & \\
\hline $\mathrm{T}_{1}$ & Control (only Plum) & 332.00 & 17.96 & 136.40 & 6.41 & 0.26 & 5.65 \\
\hline $\mathrm{T}_{2}$ & Control (only Greengram) & 333.02 & 17.11 & 137.00 & 6.46 & 0.27 & 5.60 \\
\hline $\mathrm{T}_{3}$ & FYM & 336.07 & 18.91 & 139.33 & 6.60 & 0.30 & 6.00 \\
\hline $\mathrm{T}_{4}$ & Dalweed Manure & 334.06 & 18.11 & 138.00 & 6.49 & 0.29 & 5.90 \\
\hline $\mathrm{T}_{5}$ & Biofertiliser (Rhizobium) & 335.00 & 18.00 & 140.00 & 6.68 & 0.28 & 5.70 \\
\hline $\mathrm{T}_{6}$ & Vermicompost & 339.51 & 20.05 & 143.61 & 6.78 & 0.30 & 6.20 \\
\hline $\mathrm{T}_{7}$ & Biofertiliser + Vermicompost $(50 \%)$ & 337.93 & 19.08 & 142.81 & 6.74 & 0.31 & 5.85 \\
\hline $\mathrm{T}_{8}$ & $\begin{array}{l}80 \% \text { of recommended doses of NPK }+ \text { FYM }+ \\
\text { Dalweed }+ \text { Biofertiliser (Rhizobium) }\end{array}$ & 346.82 & 23.15 & 150.82 & 6.89 & 0.33 & 6.40 \\
\hline $\mathrm{T}_{9}$ & $\begin{array}{l}60 \% \text { of recommended doses of NPK }+ \text { FYM }+ \\
\text { Dalweed }+ \text { Biofertiliser (Rhizobium) }\end{array}$ & 343.13 & 21.00 & 147.32 & 6.85 & 0.32 & 6.10 \\
\hline & SEm \pm & 0.70 & 0.11 & 0.15 & 0.01 & 0.01 & 0.01 \\
\hline & $C D(p \leq 0.05)$ & 2.13 & 0.33 & 0.47 & $\mathbf{0 . 0 3}$ & $\mathbf{0 . 0 2}$ & 0.04 \\
\hline
\end{tabular}


Data pertaining to available $\mathrm{N}, \mathrm{P}$ and $\mathrm{K}$ revealed that different doses of organic manures and fertilizers significantly influenced the amount of available $\mathrm{N}, \mathrm{P}$ and $\mathrm{K}$ in surface soil. Addition of organic manures with lower C:N ratio (less than 20:1) increases the microbial activity, thereby, accelerating the rate of mineralization. This might have lead to greater release of $\mathrm{N}$ from native organic sources, ultimately, resulting in higher $\mathrm{N}$ content in soils. Raina and Goswami (1988) have also reported that the addition of organic material accelerates the decomposition of native soil organic matter (a positive priming effect) thus, leading to higher mineralization and release of nutrient elements. Other workers Sreenivas et al., (2000), Marimuthu et al., (2001) and Singh et al., (2002) have also reported that the inclusion of organic amendments and inorganic fertilizers at variable rates increased the soil $\mathrm{N}, \mathrm{P}$ and $\mathrm{K}$ content. Prakash et al., (2002) in their study on comparative efficacy of organic manures and inorganic fertilizers in relation to nutrient availability, reported higher availability of all major nutrient elements in treatments supplemented with organic nutrient sources compared to manures and fertilizers alone.

In conclusion, the results obtained from the present investigation indicated that the green gram plants thrive well under plum based agroforestry system and can be cultivated successfully as intercrop with fruit trees. The use of organic manures and chemical fertilizers in combination has been found to be more efficient than organic manures alone. Different doses of organic manures and fertilizers are found to be having influence on available nitrogen, available potassium, and available phosphorus.

\section{References}

Agele, S.O. 2000. Effects of animal manure and NPK fertilizer on stimulated erosion and maize yield. J. Environ. Educational Information, 19(2): 131138.

Anonymous. 2010. Economic Survey, Directorate of Economics and Statistics, Jammu and Kashmir, pp. 131-143.

Anonymous. 2011. Statement showing the district-wise area and production of main fruits in Jammu and Kashmir. Department of Horticulture, Jammu and Kashmir.

Anonymous. 2012. Agricultural Research Databook-2012. Indian Council of Agricultural Research, Krishi Bhawan, New Delhi, pp. 151-153.

Bhatt, R.K., Suresh, G. and Newaj, R. 2003. Biophysical aspects of tree crop interactions in silvopastoral system. In: Agroforestry Potential and Opportunities (Eds. P.S. Pathak and R. Newaj). Agrobios (India) and Indian Society of Agroforestry, pp. 54-64.

Bijalwan, A. 2010. Assessment of seasonal soil moisture under traditional agroforestry systems in Garhwal Himalaya, India. J. Progressive Agri., 1(1): 4-7.

Fernandes, E. and Nair, P.K.R. 1986. An evaluation of the structure and function of tropical home gardens. Agroforestry Systems, 21: 279-310.

Gomez, K.A. and Gomez, A.A. 1984. Statistical procedures for agricultural research, $2^{\text {nd }}$ ed. New York: John Willey and Sons, p. 680.

Gupta, S.C., Dowdy, R.H. and Larson, W.E. 1977. Hydraulic and thermal properties of a sandy soil as influenced by incorporation of sewage sludge. Soil Sci. Am. Proc., 41: 601-605.

Huxley, P.A. 1996. Biological factors affecting form and function in woody, non-woody plant mixtures. In: Tree Crop Interactions $-A$ Physiol. Approach, (Eds. K.O. Chin and P.A. Huxley), pp. 295-298. 
Jackson, M.L. 1973. Soil chemical analysis. $2^{\text {nd }}$ medium reprint, Prentice Hall of India, New Delhi, pp 498.

Jayabhaskaran, K.J., Pandey, S.D., Mustaffa, M.M. and Sathyamoorthy, S. 2001. Effect of different organic manures with graded levels of inorganic fertilizers on ratios of Poovan banana. South Indian Horticulture, 49: 105-106.

Khaleel, R., Reddy, K.R. and Overcash, M.R. 1981. Changes in soil physical properties due to organic waste applications: a review. J. Environ. Quality, 10: 133-141.

Marimuthu, R., Athmanathan, V. and Mohandas, S. 2001. Integrated nutrient management for coconut. South Indian Horticulture, 49: 145-147.

Metzger, L. and Yaron, B. 1987. Influence of sludge organic matter on soil physical properties. Adv. Soil Sci., 7: 141-163.

Olsen, S.R., Cole, C.V., Watanate, I.S. and Dean, L.A. 1954. Estimation of available phosphorus in soils by extraction with sodium bicarbonate. US Department of Agriculture, Washington, D.C. Circular No. 939.

Piper, C.S. 1966. Soil and plant analysis. Hans W.S. Publishers, Bombay, pp 464.

Prakash, Y.S., Bhadoria, P.B.S. and Rakshit, A. 2002. Comparative efficacy of organic manures on the changes in soil properties and nutrient availability in an alfisol. J. Indian Society of Soil Sci., 50(3): 219-221.

Raina, J.N. and Goswami, K.P. 1988. Effect of added 14C labelled materials on the decomposition of native soil organic matter. J. Indian Society of Soil Sci., 36: 645-651.

Singh, S., Singh, R.N., Prasad, J. and Kumar, B. 2002. Effect of green manuring, FYM and biofertilizer in relation to fertilizer nitrogen on yield and major nutrient uptake by upland rice. J. Indian Society of Soil Sci., 53(3): 207-213.

Sreenivas, C., Muralidhar, S. and Rao, M.S. 2000. Vermicompost a viable component of IPNSS in nitrogen nutrition of ridge gourd. Annals of Agri. Res., 21(1): 108-113.

Srikanth, K., Srinivasamurthy, C.A., Siddaramappa, R. and Parama R.V.R. 2000. Direct and residual effect of enriched composts, FYM, vermicompost and fertilizers on properties of alfisol. J. Indian Soc. Soil Sci., 48(3): 496-499.

Subbiah, B.V. and Asija, G.L. 1956. A rapid procedure for the estimation of available nitrogen in soils. Curr. Sci., 25: 259-260.

Vijay, S.B.M., Mastan R.C., Subramanyam, A. and Balaguravaiah, D. 2007. Effect of integrated use of organic and inorganic fertilizers on soil properties and yield of sugarcane. J. Indian Society for Soil Sci., 55: 161-166.

Westwood, M.N. 1993. Temperate Zone Pomology. W.H. Freeman and Company San Francisco, California, USA, p. 223.

\section{How to cite this article:}

Murtaza Hussain Shah, Vaishnu Dutt, S.J.A. Bhat, Zubair A. Dar and Mehraj ud din Khanday. 2017. Characteristics of Soil under Greengram-Plum based Agroforestry System in Kashmir Valley, India. Int.J.Curr.Microbiol.App.Sci. 6(5): 1615-1622.

doi: https://doi.org/10.20546/ijcmas.2017.605.176 